\title{
Mini Review \\ JAMUR ENDOFIT, BIODIVERSITAS, POTENSI DAN PROSPEK PENGGUNAANNYA SEBAGAI SUMBER BAHAN OBAT BARU
}

\author{
Hadi Kuncoro ${ }^{1)}$ dan Noor Erma Sugijanto ${ }^{2)}$ \\ Kelompok Bidang Ilmu Biologi Farmasi Fakultas Farmasi Universitas Mulawarman ${ }^{1)}$. \\ Jl. Penajam, Kampus Unmul Gunung Kelua, Samarinda, Kalimantan Timur. \\ e-mail: hadikuncoro@farmasi.unmul.ac.id \\ Departemen Kimia Farmasi Fakultas Farmasi Universitas Airlangga, Surabaya, Jawa Timur ${ }^{2}$.
}

\begin{abstract}
Endhophytes microbes are microbes that live in colonies formed in plant tissues without harming its host plant. Endhophytes was first reported in 1904. Each higher plants may contain some Endhophytes microbes that produce secondary metabolites as a product of coevolution or genetic transfer occurred (genetic recombination) from its host plants to microbial Endhophytes. Endhophytes originating from areas with high biodiversity have the potential to generate chemical diversity is also high and has a future economic prospects.
\end{abstract}

Key words : Endhophytes, genetic transfer, biodiversity

\begin{abstract}
ABSTRAK
Mikroba Endofit adalah mikroba yang hidup membentuk koloni di dalam jaringan tanaman tanpa membahayakan tanaman inangnya. Endofit dilaporkan pertama kali pada tahun 1904. Setiap tanaman tingkat tinggi dapat mengandung beberapa mikroba endofit yang menghasilkan metabolit sekunder sebagai akibat koevolusi atau terjadi transfer genetik (genetic recombination) dari tanaman inangnya ke mikroba endofit. Endofit yang berasal dari daerah dengan biodiversitas tinggi memiliki potensi menghasilkan keanekaragaman kimiawi yang juga tinggi dan mempunyai prospek ekonomi dimasa depan.
\end{abstract}

Kata kunci : Endofit, transfer genetik, biodiversitas.

\section{PENDAHULUAN}

Dua abad terakhir ini, setidaknya ada tiga jenis revolusi dalam industri; yaitu batubara dan kereta api, minyak dan senyawa kimia serta yang terakhir elektronika dan bioteknologi. Revolusi industri bioteknologi, sebagai hasil dari penemuan dan meluasnya pengetahuan dasar tentang proses kehidupan pada tingkat molekul, sel dan genetik saat ini sangat menarik perhatian para peneliti dan pihak industri. Melalui bioteknologi, berbagai permasalahan biologi yang pada masa lampau belum diketahui jawabannya, sekarang telah dapat dipecahkan. Berangkat dari pemikiran bahwa bioteknologi sebagai sebuah sistem pendekatan baru dalam mengubah bahan mentah melalui proses biologi menjadi produk berguna, maka paduan ilmu biologi, biokimia dan rekayasa ini diharapkan dan telah terbukti menghasilkan beragam penemuan baru atau penyempurnaan dalam pemecahan masalah dibidang kesehatan, pertanian dan lingkungan [1]. 
Saat ini diketahui sekitar $30 \%$ penjualan obat diseluruh dunia adalah obat-obatan yang berasal dari bahan alam. Di Amerika Serikat misalnya sekitar $25 \%$ dari obat yang diresepkan, komposisi utamanya adalah produk alami yang berasal dari tanaman dan turunannya [12].

Sebagai contoh aspirin, analgesik yang saat ini paling dikenal adalah hasil isolasi dari tanaman Salix dan Spiraea, demikian pula paclitaxel dan vinblastine merupakan obat antikanker yang sangat potensial juga diisolasi dari tanaman. [4].

Tingkat produksi obat herbal khususnya, saat ini masih sangat terbatas karena sebagian besar bahan baku masih diambil dari tanaman aslinya. Dikhawatirkan sumberdaya hayati ini suatu saat musnah disebabkan kendala dalam budidayanya dan peningkatan produksi yang sejalan dengan meningkatnya permintaan akibat berkembangnya populasi. Bahkan disinyalir bahan obat herbal yang diproduksi dan diedarkan di Indonesia saat ini sebagian besar bahan bakunya sudah mulai diimpor dari negara lain[4].

Masalah kesinambungan suplai bahan baku obat dan pengembangan obat baru dari bahan alam yang sumbernya relatif terbatas ini merupakan hal yang mendesak untuk dicari solusinya [6].

Peran bioteknologi dalam budidaya, multiplikasi, rekayasa genetika, dan skrining tumbuhan maupun mikroba yang diharapkan menghasilkan metabolit sekunder berkhasiat sangat penting dalam rangka pengembangan bahan obat yang berasal dari bahan alam ini [4].

Secara historis dari semua mikroorganisme yang telah diteliti, Actinomycetes dan jamur merupakan penghasil metabolit sekunder yang sangat beragam dan

J. Trop. Pharm. Chem. 2011. Vol 1. No. 3. potensial [2]. Sejak ditemukannya penisilin tahun 1928 yang kemudian diikuti beragam antibiotika sesudahnya seperti golongan streptomisin, jamur menarik perhatian para peneliti untuk dieksplorasi sebagai sumber bahan obat [6]. Salah satu bentuk perkembangan bioteknologi dalam hal ini adalah peningkatan produksi metabolit sekunder melalui mikroba khususnya jamur melalui proses fermentasi. Hal ini dilakukan untuk menghasilkan produk metabolit sekunder yang bersifat unggul dan dalam jumlah melimpah. Diantara berbagai mikroorganisme yang dikembangkan potensinya sebagai sumber bahan obat saat ini dan menjadi perhatian para peneliti adalah mikroba endofit.

\section{Mikroba Endofit}

Endofit dilaporkan pertama kali pada tahun 1904 oleh Darnel dkk. Mikroba endofit didefinisikan sebagai mikroba yang hidup di dalam jaringan tumbuhan tanpa menyebabkan efek negatif langsung yang nyata seperti dikemukakan oleh Stone dkk. Hal ini menunjukkan kemungkinan terjadi hubungan simbiosis mutualisme antara mikroba endofit dan tanaman inangnya, namn ternyata ada pula endofit yang saprofit agresif atau patogen oportunis. Mikroba endofit umumnya berupa bakteri dan kapang, namun jenis kapang yang lebih sering diisolasi [5].

Bakteri adalah prokariota dan jamur adalah eukariota. Bakteri pada umumnya berkolonisasi di jaringan intraseluler, jamur dapat ditemukan dalam jaringan intermaupun intraseluler [7].

Tan dan Zou menyatakan bahwa mikroba endofit adalah mikroba yang hidup membentuk koloni di dalam jaringan tanaman tanpa membahayakan tanaman inangnya. Setiap tanaman tingkat tinggi dapat mengandung beberapa mikroba 
endofit yang menghasilkan metabolit sekunder sebagai akibat koevolusi atau terjadi transfer genetik (genetic recombination) dari tanaman inangnya ke mikroba endofit [13]. Kemampuan mikroba endofit menghasilkan berbagai senyawa fitokimia tertentu yang juga dihasilkan oleh tumbuhan inangnya mungkin terkait dengan adanya rekombinasi genetik mikroba endofit dengan inang selama waktu evolusinya. Konsep tersebut sebelumnya diusulkan sebagai mekanisme untuk menjelaskan mengapa Taxomyces andreanae yang diisolasi dari Taxus brevifolia dapat menghasilkan taxol seperti tanaman inangnya [13].

Kemampuan mikroba endofit memproduksi senyawa metabolit sekunder yang sama dengan tanaman inangnya merupakan peluang yang sangat besar dan dapat diandalkan untuk memproduksi metabolit sekunder melalui mikroba endofit yang diisolasi dari tanaman inangnya tersebut. Apabila mikroba endofit dapat menghasilkan senyawa-senyawa bioaktif yang langka dan penting seperti yang dimiliki tanaman inangnya, maka endofit dapat mengurangi ketergantungan terhadap sumber bahan baku dari tanaman inangnya, dengan demikian keanekaragaman hayati yang ada dapat dipertahankan. Selain itu, penggunaan mikroba sebagai sumber produk metabolit sekunder yang berkhasiat dapat dilakukan dengan proses yang lebih mudah dan ekonomis, sehingga dapat dihasilkan produk dengan harga lebih kompetitif [13].

Hawksworth dan Rossman memperkirakan terdapat sekitar 1 juta spesies jamur, 100.000 diantaranya jenisnya telah dikenal [10]. Diketahui terdapat sekitar 300.000 jenis tanaman tersebar di muka bumi ini, bila masing-masing tanaman mengandung satu atau lebih mikroba endofit yang terdiri dari bakteri dan jamur, bisa dibayangkan betapa besar kekayaan biodiversitasnya [9]. Mikroba endofit merupakan sumber keanekaragaman genetik yang kaya dan dapat diandalkan dengan berbagai kemungkinan spesies baru yang belum dideskripsikan. Mengingat biodiversitasnya yang sangat kaya tersebut maka kebutuhan akan produk bahan alam yang digunakan sebagai antibiotik baru, bahan kemoterapi dan agrokimia yang memiliki kefektifan tinggi, toksisitas rendah, namun tidak menganggu ekologi lingkungan dapat diharapkan diperoleh dari mikroba endofit ini [10].

\section{Tanaman inang dan mikroba endofit}

Pemanfaatan mikroba endofit sebagai sumber metabolit sekunder berkhasiat perlu didasari pada pemilihan tumbuhan inang yang tepat untuk diisolasi endofitnya. Pilihan tumbuhan inang akan mempengaruhi keunikan dan aktivitas biologis produk yang dihasilkan oleh mikroba endofit tersebut [4]. Strobel dan Daisy, 2003 mengemukakan beberapa strategi pemilihan tanaman inang untuk diisolasi endofitnya dan kaitannya dengan produk bahan alam yang dihasilkan diantaranya adalah :

(a). Tanaman yang berasal dari lingkungan yang unik, khususnya dengan kondisi biologis yang tidak umum/ekstrem, kemungkinan menghasilkan senyawa novel yang digunakannya untuk bertahan hidup. (b). Tanaman yang memiliki sejarah etnobotani (digunakan oleh penduduk lokal untuk pengobatan). Pemilihan tanaman dapat dilakukan langsung dengan bantuan penduduk lokal disekitar daerah tempat hidup tanaman tersebut atau didasarkan catatan-catatan pengobatan yang telah ada. (c). Tanaman endemik, atau yang hanya hanya hidup di wilayah tertentu atau pada waktu tertentu. (d). Tanaman yang tumbuh 
didalam wilayah dengan biodiversitas tinggi.

Endofit yang berasal dari daerah dengan biodiversitas tinggi memiliki potensi menghasilkan keanekaragaman kimiawi yang juga tinggi dan mempunyai prospek ekonomi dimasa depan [10]. Tidak hanya tanaman yang berasal dari lingkungan dengan biotipe khusus yang menjadi sumber endofit novel dan novel metabolit sekunder tetapi juga dari lingkungan yang ekstrem. Tanaman air Rhyncholacis penicillatta merupakan salah satu contoh tanaman yang tetap tumbuh subur walaupun berada dekat dengan tempat pembuangan limbah di sungai di Venezuela. Endofit yang ditemukan dalam tanaman ini adalah Serratia marcescens yang menghasilkan oocydin $A$, yaitu komponen novel antioomycetous dengan struktur lakton makrosiklik terklorinasi [10].

Sejauh ini, tanaman yang telah diteliti endofitnya masih sangat sedikit, oleh karena itu, masih terbuka kesempatan untuk menemukan berbagai jenis endofit baru yang mengandung metabolit sekunder yang berkhasiat. Bills dkk menyatakan hutan hujan tropis merupakan daerah yang berpotensi luar biasa sebagai sumber endofit tropis yang unggul dengan beragam produk metabolit sekunder aktif dibandingkan endofit dari daerah subtropis [9].

\section{Isolasi Endofit dari bagian tanaman.}

Tujuan melakukan isolasi jamur endofit terutama untuk mendapatkan produk metabolit sekunder yang aktif secara biologis [12]. Secara umum prosedur mengisolasi endofit tidaklah terlalu rumit, terutama bagi yang memiliki dasar teknik mikrobiologi. Setelah dilakukan proses pemilihan, identifikasi dan penentuan lokasi tanaman, selanjutnya bagian tanaman diambil dan disimpan sementara dengan menggunakan wadah plastik khusus yang berpori. Penyimpanan tanaman dalam wadah yang tertutup rapat dengan tujuan memperlambat proses pengeringan jaringan tanaman, tetapi karena ketidakseimbangan aerasi dapat menyebabkan kontaminasi maupun kematian jaringan. Penyimpanan material tanaman dipertahankan pada suhu $4{ }^{\circ} \mathrm{C}$ sampai prosedur isolasi dimulai.

Dilakukan proses sterilisasi permukaan dengan perendaman material tanaman menggunakan etanol $70 \%$ dan $\mathrm{NaOCl}$ selama beberapa menit. Tujuan pemakaian etanol dan $\mathrm{NaOCl}$ untuk mengeliminasi kontaminasi mikroba pada permukaan. Waktu perendaman bervariasi tergantung jenis jaringan tanaman maupun tanaman inangnya. Diperlukan proses strelisasi dan perendaman lebih lama untuk jaringan kayu ataupun daun dengan kutikula yang tebal. Kombinasi Etanol-NaOCl-Etanol terbukti efektif membunuh spora yang dihasilkan oleh jamur kontaminan. Setelah dilakukan sterilisasi pada bagian permukaan, dilanjutkan dengan proses pemindahan jaringan menggunakan pisau bedah steril untuk mendapatkan epidermis, kambium, xylem, dan floem, kemudian ditanam dalam medium yang sesuai untuk memberi kesempatan jamur endofit tumbuh [12]. Inkubasi dilakukan pada suhu ruangan selama beberapa hari, selanjutnya ujung-ujung hypa yang tumbuh dari jamur endofit dipindahkan ke media agar yang sesuai. Setelah tahap pemurnian, endofit dari kultur murni di uji kemampuan tumbuhnya dengan beragam media dan berbagai kondisi pertumbuhan. Penyimpanan kultur dapat dilakukan dengan kondisi tertentu misalnya dengan penambahan gliserol $15 \%$ pada suhu $-70{ }^{\circ} \mathrm{C}$. Selanjutnya mikroba yang diperoleh difermentasikan, metabolitnya 
Jamur Endofit, Biodiversitas, Potensi Dan Prospek Penggunaannya Sebagai Sumber Bahan Obat Baru

diekstraksi yang kemudian komponen bioaktifnya diisolasi dan dikarakterisasi [10].

Berbagai jenis endofit telah berhasil diisolasi dari tanaman inangnya, dan telah berhasil dibiakkan dalam media perbenihan yang sesuai. Metabolit sekunder yang diproduksi mikroba endofit tersebut telah berhasil di isolasi, dimurnikan serta telah dielusidasi struktur molekulnya. Ketertarikan para peneliti terhadap metabolit sekunder yang berasal dari mikroba endofit banyak ditampilkan dalam beberapa jurnal ilmiah. Gusman dan Van haelen mendeskripsikan metabolit sekunder dan aktifitas biologi dari 38 jenis jamur endofit, sementara Tan dan Zou mendeskripsikan setidaknya ada 138 metabolit sekunder dari endofit [2].

Berikut ini disarikan dalam tabel 1 beragam metabolit sekunder yang berasal dari mikroba endofit.

Tabel I. Produk alami dari mikroba endofit

\begin{tabular}{|c|c|c|c|c|}
\hline Jenis mikroba & $\begin{array}{c}\text { Tanaman inang } \\
\text { (family)bagian tanaman } \\
\text { atau jaringan }\end{array}$ & Kondisi kultur & Produk alami & Aktifitas biologi \\
\hline $\begin{array}{l}\text { Acremonium zeae } \\
\text { (NRRL 13540) } \\
\text { (mitosporic } \\
\text { Hypocreales) }\end{array}$ & $\begin{array}{l}\text { Zea maydis L. (maize) } \\
\text { (Poaceae); biji }\end{array}$ & $\begin{array}{l}\text { Semua bagian biji } \\
\text { dalam } \mathrm{H}_{2} \mathrm{O} ; 25^{\circ} \mathrm{C} ; \\
30 \text { hari }\end{array}$ & $\begin{array}{l}\text { pyrrocidine } \mathrm{A} \\
\text { pyrrocidine } \mathrm{B}\end{array}$ & antibakteri; antijamur \\
\hline Acremonium spp. & Taxus baccata $\mathrm{L}$. & & leucinostatin $\mathrm{A}$ & $\begin{array}{l}\text { anti-oomycetes dan } \\
\text { antikanker } \\
\text { (melanoma G361, HT- } \\
\text { 144,Leukaemia cell lines } \\
\text { HSB-2,K-562) }\end{array}$ \\
\hline $\begin{array}{l}\text { Aspergillus clavatus } \\
\text { strain } \mathrm{H}-037 \\
\text { (Trichocomaceae) }\end{array}$ & $\begin{array}{l}\text { Taxus mairei (Lemee \& } \\
\text { Lev.) dan Torreya grandis } \\
\text { Arn. (Taxaceae); kulit } \\
\text { batang }\end{array}$ & PDA; ; $25^{\circ} \mathrm{C} ; 7$ hari & brefeldin $\mathrm{A}$ & $\begin{array}{l}\text { antijamur; } \\
\text { antiviral;antikanker; } \\
\text { Manajemen rumput }\end{array}$ \\
\hline $\begin{array}{l}\text { Aspergillus fumigates } \\
\text { CY018 } \\
\text { (Trichocomaceae) }\end{array}$ & $\begin{array}{l}\text { Cynodon dactylon (L.) } \\
\text { Pers. (Poaceae); daun }\end{array}$ & $\begin{array}{l}\text { Medium millet } \\
\text { (padat); } 28^{\circ} \mathrm{C} ; 35 \\
\text { hari }\end{array}$ & $\begin{array}{l}\text { asperfumoid } \\
\text { asperfumin } \\
\text { monometilsulokrin } \\
\text { fumigaklavin C } \\
\text { fumitremorgin C } \\
\text { physcion } \\
\text { ergosterol } \\
\text { helvolic acid } \\
5 \alpha, 8 \alpha \text {-epidioksi- } \\
\quad \text { ergesterol } \\
\text { cycla(A la-Leu) } \\
\text { cyclo(A la-Ile) }\end{array}$ & $\begin{array}{l}\text { antifungi; } \\
\text { mikotoksin } \\
\text { antifungi; } \\
\text { mikotoksin }\end{array}$ \\
\hline $\begin{array}{l}\text { Aspergillus niger IFB- } \\
\text { E003 } \\
\text { (Trichocomaceae) }\end{array}$ & $\begin{array}{l}\text { Cynodon dactylon (L.) } \\
\text { Pers. (Poaceae); daun }\end{array}$ & $\begin{array}{l}\text { Medium millet-bran } \\
\text { (padat) } 28^{\circ} \mathrm{C} ; 35 \\
\text { hari }\end{array}$ & $\begin{array}{l}\text { rubrofusarin B } \\
\text { Fonsecinone A } \\
\text { aurasperon A } \\
\text { asperpyron B }\end{array}$ & $\begin{array}{l}\text { sitotoksik } \\
\text { oksidasi ksantin inhibitor } \\
\text { sitotoksik } \\
\text { oksidasi ksantin inhibitor }\end{array}$ \\
\hline \multirow[t]{2}{*}{$\begin{array}{l}\text { Aspergillus parasiticus } \\
\text { RDWDI-2 } \\
\text { (Trichocomaceae) }\end{array}$} & \multirow[t]{2}{*}{$\begin{array}{l}\text { Sequoia sempervirens } \\
\text { (D.Don) } \\
\text { Endl. (Taxodiaceae); } \\
\text { Kulit batang }\end{array}$} & $\begin{array}{l}\text { DIFCO mycological } \\
\text { broth } ; 19 \text { hari; } \\
\text { ekstrak mycelia }\end{array}$ & $\begin{array}{l}\text { sequoiaton } \mathrm{C} \\
\text { sequoiaton } \mathrm{D} \\
\text { sequoiaton } \mathrm{E} \\
\text { sequoiaton } \mathrm{F}\end{array}$ & \multirow{2}{*}{$\begin{array}{l}\text { toksik terhadap larva udang } \\
\text { toksik terhadap larva udang } \\
\text { toksik terhadap larva udang } \\
\text { toksik terhadap larva udang } \\
\text { toksik terhadap larva udang } \\
\text { sitotoksik } \\
\text { toksik terhadap larva udang } \\
\text { toksik terhadap larva udang } \\
\text { toksik terhadap larva udang }\end{array}$} \\
\hline & & $\begin{array}{l}\text { DIFCO mycological } \\
\text { broth } ; 21 \text { hari; } \\
\text { ekstrak mycelia }\end{array}$ & $\begin{array}{l}\text { sequoiamonanascin A } \\
\text { sequoiamonanascin B } \\
\text { sequoiamonanascin C } \\
\text { sequoiamonanascin D }\end{array}$ & \\
\hline $\begin{array}{l}\text { Aspergillus } \mathrm{sp} . \\
\text { (strain\#CY725) } \\
\text { (Trichocomaceae) }\end{array}$ & $\begin{array}{l}\text { Cynodon dactylon (L.) } \\
\text { Pers. (Poaceae); daun }\end{array}$ & $\mathrm{PDB} ; 28^{\circ} \mathrm{C} ; 4$ hari & $\begin{array}{l}\text { Monometilsulokrin } \\
\text { helvolic acid } \\
\text { ergosterol } \\
5 \alpha, 8 \alpha \text {-epidioksi- } \\
\quad \text { ergesterol } \\
\end{array}$ & $\begin{array}{l}\text { antibakteri;eosinofil } \\
\text { inhibitor } \\
\text { antibakteri }\end{array}$ \\
\hline
\end{tabular}


Jamur Endofit, Biodiversitas, Potensi Dan Prospek Penggunaannya Sebagai Sumber Bahan Obat Baru

Tabel I. Produk alami dari mikroba endofit (lanjutan)

\begin{tabular}{|c|c|c|c|c|}
\hline Jenis mikroba & $\begin{array}{c}\text { Tanaman inang } \\
\text { (family)bagian tanaman } \\
\text { atau jaringan }\end{array}$ & Kondisi kultur & Produk alami & Aktifitas biologi \\
\hline $\begin{array}{l}\text { Botrytis sp. } \\
\text { (Sclerotiniceae) }\end{array}$ & $\begin{array}{l}\text { Taxus brevifolia Nutt. } \\
\text { (Taxaceae); kulit batang }\end{array}$ & $\begin{array}{l}\text { DIFCO mycological } \\
\text { broth;still kultur;21 } \\
\text { hari }\end{array}$ & $\begin{array}{l}\text { ramulosin } \\
\text { 6-hidroksiramulosin } \\
\text { 8-dihidroramulosin }\end{array}$ & $\begin{array}{l}\text { antibakteri } \\
\text { antibakteri } \\
\text { antibakteri }\end{array}$ \\
\hline $\begin{array}{l}\text { Cephalosporium sp. } \\
\text { IFB-E001 } \\
\text { (mitosporic } \\
\text { Hypocreales) }\end{array}$ & $\begin{array}{l}\text { Trachelospermum } \\
\text { Jasmoides Lemoire } \\
\text { (Apocynaceae);vine }\end{array}$ & $\begin{array}{l}\text { Medium Millet- } \\
\text { bran(padat); } 28^{\circ} \mathrm{C} ; \\
30 \text { hari }\end{array}$ & graphislakton $\mathrm{A}$ & $\begin{array}{l}\text { antioksidan; } \\
\text { antiradikal bebas }\end{array}$ \\
\hline Colletotrichum spp. & $\begin{array}{l}\text { Artemisia annua } \\
\text { L. (tanaman herbal dari } \\
\text { cina) }\end{array}$ & & $\begin{array}{l}\text { 6-isoprenil indole-3- } \\
\text { Asam karboksilat, } \\
3 \beta, 5 \alpha \text { dihidroksi-6 } \beta- \\
\text { asetoksi-ergosta- } \\
7,22-\text { diene } \\
3 \beta, \quad 5 \alpha \text { dihidroksi-6 } \beta \text { - } \\
\text { fenil asetiloksi- } \\
\text { ergosta-7,22-diene }\end{array}$ & $\begin{array}{l}\text { aktifitas antimikroba } \\
\text { terhadap jamur pathogen } \\
\text { pada manusia dan bakteri, } \\
\text { Fungistatic terhadap jamur } \\
\text { patogenik pada tanaman }\end{array}$ \\
\hline $\begin{array}{l}\text { Colletotrichum } \\
\text { gloeosporioides }\end{array}$ & $\begin{array}{l}\text { Artemisia mongolica } \\
\text { Fisch. ex Bess. }\end{array}$ & & Colletotric acid & $\begin{array}{l}\text { antibakteri dan anti fungi } \\
\text { (Helminthosporium } \\
\text { sativum) }\end{array}$ \\
\hline $\begin{array}{l}\text { Cephalosporium sp. } \\
\text { (mitosporic } \\
\text { Hypocreales) }\end{array}$ & $\begin{array}{l}\text { Dendrobium nobile Sw. } \\
\text { (Orchidaceae); akar }\end{array}$ & $\begin{array}{l}\text { Medium wheat bran } \\
\text { (cair); } 25^{\circ} \mathrm{C} ; 7 \text { hari }\end{array}$ & $\begin{array}{l}\text { ergosterol } \\
\text { cyclo (Gly-Val) } \\
\text { butanedioic acid } \\
\text { kolin sulfat } \\
\text { 2-[2-(hidroksil- } \\
\quad \text { tetrakosanol)amino- } \\
\quad \text { 1,3,4-oktadekatriol } \\
\quad \text { leusin } \\
\text { D-mannitol } \\
\text { meso-eritriol } \\
\text { piridin-3-asam } \\
\text { karboksilat } \\
\alpha \text {-sterain } \\
\text { urasil }\end{array}$ & \\
\hline $\begin{array}{l}\text { Ceratopycnidium } \\
\text { Baccharidicola } \\
\text { (Ascomycetes, inserte } \\
\text { sedis) }\end{array}$ & $\begin{array}{l}\text { Baccharis cordifolia } \mathrm{L} \text {. } \\
\text { (Asteraceae); batang dan } \\
\text { daun }\end{array}$ & $\begin{array}{l}\text { Medium YES; } \\
\text { medium myro; } \\
\text { medium beras padat; } \\
24-27{ }^{\circ} \mathrm{C} ; 30 \text { hari }\end{array}$ & $\begin{array}{l}\text { rodisins } \\
\text { verrukarins }\end{array}$ & $\begin{array}{l}\text { toksik to livestock } \\
\text { toksik to livestock }\end{array}$ \\
\hline $\begin{array}{l}\text { Colletotrichum sp. } \\
\text { Strain EG } \\
\text { 4(phyllachoraceae) }\end{array}$ & $\begin{array}{l}\text { Ginko biloba } \mathrm{L} \text {. } \\
\text { (ginkgoaceae); daun }\end{array}$ & PDB; $28^{\circ} \mathrm{C} ; 6$ hari & komponen mirip flavon & \\
\hline $\begin{array}{l}\text { Chaetornium chiversii } \\
\text { CS-36-62 } \\
\text { (Chaetomiaceae) }\end{array}$ & $\begin{array}{l}\text { Ephedra fasciculata } \\
\text { A.Nels (Ephedraceae); } \\
\text { Batang }\end{array}$ & PDA; $27{ }^{\circ} \mathrm{C} ; 14$ hari & radicikol & $\begin{array}{l}\text { sitotoksik;Hsp90 } \\
\text { Inhibitor }\end{array}$ \\
\hline $\begin{array}{l}\text { Chaetomium globosum } \\
\text { (Chaetomiaceae) }\end{array}$ & $\begin{array}{l}\text { Ephedra fasciculata } \\
\text { A.Nels (Ephedraceae); } \\
\text { Batang }\end{array}$ & PDB; $26{ }^{\circ} \mathrm{C} ; 15$ hari & $\begin{array}{l}\text { asam orsellinik } \\
\text { globosumone A } \\
\text { globosumone B } \\
\text { globosumone C } \\
\text { trichodion } \\
\text { orcinol }\end{array}$ & $\begin{array}{l}\text { sitotoksik } \\
\text { sitotoksik }\end{array}$ \\
\hline $\begin{array}{l}\text { Cladosporium } \\
\text { herbarium } \\
\text { IFB-E002 } \\
\text { (Mycosphaerellacea) }\end{array}$ & $\begin{array}{l}\text { Cynodon dactylon (L.) } \\
\text { Pers. (Poaceae); daun }\end{array}$ & $\begin{array}{l}\text { Medium Millet- } \\
\text { bran(padat); } 28{ }^{\circ} \mathrm{C} ; \\
35 \text { hari }\end{array}$ & $\begin{array}{l}\text { asperginin A } \\
\text { rubrofusarin B } \\
\text { fonsecinone A } \\
3 \alpha, 5 \alpha, 6 \beta \text {-trihidroksi- } \\
\text { ergosta-7,22-diene } \\
\text { 7-hidroksi-4-metoksi-5- } \\
\text { metilkumarin } \\
\text { Orlandin } \\
\text { kotanin }\end{array}$ & $\begin{array}{l}\text { sitotoksik;ksantin oksidase } \\
\text { inhibitor } \\
\text { plant growth inhibitor }\end{array}$ \\
\hline $\begin{array}{l}\text { Cytospora sp. CR } 200 \\
\text { (Valsaceae) }\end{array}$ & $\begin{array}{l}\text { Conocarpus erecta } \mathrm{L} . \\
\text { (Combretaceae); batang }\end{array}$ & PDB & $\begin{array}{l}\text { cytosporon A } \\
\text { cytosporon B } \\
\text { cytosporon C } \\
\text { cytosporon D } \\
\text { cytosporon E } \\
\text { cytoskyrin A } \\
\text { cytoskyrin B }\end{array}$ & $\begin{array}{l}\text { antijamur; sitotoksik } \\
\text { antibakteri }\end{array}$ \\
\hline
\end{tabular}

J. Trop. Pharm. Chem. 2011. Vol 1. No. 3. 
Jamur Endofit, Biodiversitas, Potensi Dan Prospek Penggunaannya Sebagai Sumber Bahan Obat Baru

Tabel I. Produk alami dari mikroba endofit (lanjutan)

\begin{tabular}{|c|c|c|c|c|}
\hline Jenis mikroba & $\begin{array}{c}\text { Tanaman inang } \\
\text { (family)bagian tanaman } \\
\text { atau jaringan }\end{array}$ & Kondisi kultur & Produk alami & Aktifitas biologi \\
\hline $\begin{array}{l}\text { Cryptosporiopsis } \\
\text { quercina }\end{array}$ & $\begin{array}{l}\text { Tripterygium wilfordii } \\
\text { Hook.f. }\end{array}$ & & $\begin{array}{l}\text { cryptocin } \\
\text { cryptocandin }\end{array}$ & $\begin{array}{l}\text { antimikosis(Pyricularia } \\
\text { oryzae dan jamur patogenik } \\
\text { terhadap tanaman lainnya) } \\
\text { Antimikotik (Sclerotinia } \\
\text { sclerotiorum, Botrytis } \\
\text { cineria) } \\
\text { aktif terhadap jamur } \\
\text { pathogen pada manusia } \\
\text { (Candida albicans, } \\
\text { Trichophyton spp.) } \\
\end{array}$ \\
\hline $\begin{array}{l}\text { Diaporthe sp. strain CR } \\
146 \\
\text { (Valsaceae) }\end{array}$ & $\begin{array}{l}\text { Forsteronia spicata } \\
\text { G. Meyer } \\
\text { (Apocynaceae); batang }\end{array}$ & PDB & $\begin{array}{l}\text { cytosporon } \mathrm{A} \\
\text { cytosporon } \mathrm{B} \\
\text { cytosporon } \mathrm{C} \\
\text { cytosporon } \mathrm{D} \\
\text { cytosporon } \mathrm{E}\end{array}$ & $\begin{array}{l}\text { antijamur;sitotoksik } \\
\text { antibakteri }\end{array}$ \\
\hline Diplodia mutila & $\begin{array}{l}\text { Quercus suber } \\
\text { L. (cork oak) }\end{array}$ & & diplopyrone & Fitotoksik \\
\hline $\begin{array}{l}\text { Dorthiorella sp. strain } \\
\text { HTF3 } \\
\text { (Botryosphaeriaceae) }\end{array}$ & $\begin{array}{l}\text { Aegiseras corniculatum } \\
\text { Gaertner. (Myrsinaceae) } \\
\text { (Mangrove); batang }\end{array}$ & PDB; $25{ }^{\circ} \mathrm{C} ; 7$ hari & $\begin{array}{l}\text { cytosporon B } \\
\text { dothiorelon A } \\
\text { dothiorelon B } \\
\text { dothiorelon C } \\
\text { dothiorelon D }\end{array}$ & $\begin{array}{l}\text { antijamur;sitotoksik } \\
\text { sitotoksik } \\
\text { sitotoksik } \\
\text { sitotoksik } \\
\text { sitotoksik }\end{array}$ \\
\hline $\begin{array}{l}\text { Eupinicillium sp. } \\
\text { (Trichocomaceae) }\end{array}$ & $\begin{array}{l}\text { Murraya panniculata } \\
\text { (L.) Jack (Rutaceae); daun }\end{array}$ & $\begin{array}{l}\text { Medium white-corn; } \\
20 \text { hari }\end{array}$ & $\begin{array}{l}\text { alanditry pinon } \\
\text { alantryfenon } \\
\text { alantrypinen } \\
\text { alantryleunon }\end{array}$ & \\
\hline $\begin{array}{l}\text { Fusarium oxysporum } \\
\text { Strain 97CG3 } \\
\text { (mitosporic } \\
\text { Hypocreales) }\end{array}$ & $\begin{array}{l}\text { Catharanthus roseus } \\
\text { (L.)G. Don } \\
\text { (Apocynaceae); kulit } \\
\text { batang bagian dalam }\end{array}$ & $\begin{array}{l}\text { Medium mineral; } \\
25^{\circ} \mathrm{C} ; 3-4 \text { hari }\end{array}$ & vineristin & antikanker \\
\hline $\begin{array}{l}\text { Fusarium sp. } \\
\text { IFB-121 } \\
\text { (mitosporic } \\
\text { Hypocreales) }\end{array}$ & $\begin{array}{l}\text { Quercus variabilis } \mathrm{L} . \\
\text { (Fagaceae); kulit batang }\end{array}$ & PDB; $28{ }^{\circ} \mathrm{C} ; 6$ hari & $\begin{array}{l}\text { cerebrosida } \\
\text { fusarusida }\end{array}$ & $\begin{array}{l}\text { antibakteri; ksantin oksidase } \\
\text { inhibitor } \\
\text { antibakteri; ksantin oksidase } \\
\text { inhibitor }\end{array}$ \\
\hline $\begin{array}{l}\text { Fusidium sp. } \\
\text { (mitosporic fungi) }\end{array}$ & $\begin{array}{l}\text { Mentha avensis } \mathrm{L} . \\
\text { (Lamiaceae); daun }\end{array}$ & $\begin{array}{l}\text { Agar biomalt } \\
\text { semisolid; atau } \\
\text { biomalt cair; } 20^{\circ} \mathrm{C} \text {; } \\
11 \text { hari }\end{array}$ & $\begin{array}{l}\text { fusidilakton A } \\
\text { fusidilakton B } \\
\text { fusidilakton C } \\
\text { cis-4-hidroksi-6- } \\
\quad \text { deoksisitalon }\end{array}$ & \\
\hline Fusarium spp & $\begin{array}{l}\text { Selaginella pallescens } \\
\text { (Pteridophyte) }\end{array}$ & & $\begin{array}{l}\text { CR377 } \\
\text { (Pentaketida) }\end{array}$ & antijamur, C. Albicans \\
\hline Fusarium Subglutinans & $\begin{array}{l}\text { Tripterygium wilfordii } \\
\text { Hook.f. }\end{array}$ & & subglutinols $\mathrm{A}$ and $\mathrm{B}$ & Imunosupresif \\
\hline $\begin{array}{l}\text { Guignardia sp. } \\
\text { (Botryospaeriaceae) }\end{array}$ & $\begin{array}{l}\text { Spondias mombin L. } \\
\text { (Anacardiaceae); daun }\end{array}$ & $\begin{array}{l}\text { Malt-peptone- } \\
\text { glucose broth; } 14 \\
\text { hari }\end{array}$ & (-)-(S)-guignardic acid & \\
\hline $\begin{array}{l}\text { Hormonema sp. ATCC } \\
74360 \\
\text { (Dothioraceae) }\end{array}$ & $\begin{array}{l}\text { Juniperus communis L. } \\
\text { (Cupressaceae); daun }\end{array}$ & $\begin{array}{l}\text { Medium padat } \\
\text { brown rice yeast; } \\
25^{\circ} \mathrm{C} ; 21 \text { hari }\end{array}$ & enfumafungin & antijamur \\
\hline $\begin{array}{l}\text { Leptoshpaeria sp. strain } \\
\text { IV403 } \\
\text { (Leptosphaeriaceae) }\end{array}$ & $\begin{array}{l}\text { Artemisia anииа L. } \\
\text { (Asteraceae); batang }\end{array}$ & PDB; $28^{\circ} \mathrm{C} ; 10$ hari & $\begin{array}{l}\text { lepthoshpaeric acid } \\
\text { leptosphaeron }\end{array}$ & \\
\hline $\begin{array}{l}\text { Melanconium } \\
\text { betulinium } \\
\text { (Melanconidiaceae) }\end{array}$ & $\begin{array}{l}\text { Betula pendula } \text { Roth; } \\
\text { B. pubescens Enrh. } \\
\text { (Betulaceae); bagian yang } \\
\text { tumbuh diatas tanah }\end{array}$ & $\begin{array}{l}\text { Medium YMG; } \\
22^{\circ} \mathrm{C} ; \text { hingga } \\
\text { sumber karbon } \\
\text { terserap sempurna }\end{array}$ & asam 3-hidroksipropionat & nematosidal \\
\hline
\end{tabular}


Jamur Endofit, Biodiversitas, Potensi Dan Prospek Penggunaannya Sebagai Sumber Bahan Obat Baru

Tabel I. Produk alami dari mikroba endofit (lanjutan)

\begin{tabular}{|c|c|c|c|c|}
\hline Jenis mikroba & $\begin{array}{c}\text { Tanaman inang } \\
\text { (family)bagian tanaman } \\
\text { atau jaringan }\end{array}$ & Kondisi kultur & Produk alami & Aktifitas biologi \\
\hline $\begin{array}{l}\text { Microsphaeropsis } \\
\text { olivacea } \\
\text { (mitosporic } \\
\text { Ascomycota) }\end{array}$ & $\begin{array}{l}\text { Pilgerodendron uviferum } \\
\text { (D.Don) Florine } \\
\text { (Cupressaceae) } \\
\text { [Gymnosperm]; phloem }\end{array}$ & $\begin{array}{l}\text { Medium beras } \\
25^{\circ} \mathrm{C} ; 30 \text { hari }\end{array}$ & $\begin{array}{l}\text { 7- hidroksi-2,4-dimetil- } \\
\quad 3(2 \mathrm{H}) \text {-benzofuranon } \\
\text { enalin } \\
\text { graphislakton } \\
\text { brotallin } \\
\text { ulokladol } \\
\text { 2,5-diacetilfenol } \\
\quad \text { butirolakton }\end{array}$ & $\begin{array}{l}\text { AChE inhibitor } \\
\text { AChE inhibitor }\end{array}$ \\
\hline $\begin{array}{l}\text { Monochaetia sp. } \\
\text { (Amphissphaeriaceae) }\end{array}$ & $\begin{array}{l}\text { Beberapa tanaman dari } \\
\text { hutan hujan; daun, batang, } \\
\text { petiola }\end{array}$ & $\begin{array}{l}\text { Medium MID } \\
\text { dengan tambahan } \\
\text { soytone } ; 23^{\circ}-24^{\circ} \mathrm{C} ; \\
21 \text { hari }\end{array}$ & amubuic acid & antimikosis \\
\hline $\begin{array}{l}\text { Muscodor albus } \\
\text { (mitosporic Xylariales) }\end{array}$ & $\begin{array}{l}\text { Cinnamomum zeylanicum } \\
\text { Schaelter. (Lauraceae); } \\
\text { batang }\end{array}$ & PDA & antibiotik volatil & antibiotik \\
\hline Muscodor roseus & $\begin{array}{l}\text { Erythophelum } \\
\text { chlorostachys (kayu besi) }\end{array}$ & & antibiotik volatil & antibakteri dan antijamur \\
\hline Muscodor roseus & $\begin{array}{l}\text { Grevillea pteridifolia } \\
\text { Knight (fern leaf tree) }\end{array}$ & & antibiotik volatil & antibakteri dan antijamur \\
\hline Muscodor vitigenus & $\begin{array}{l}\text { Paullina paullinioides } \\
\text { (Liana) }\end{array}$ & & naphthalene & $\begin{array}{l}\text { pengusir serangga terutama } \\
\text { hama pengerek batang }\end{array}$ \\
\hline $\begin{array}{l}\text { Mycelia sterila } \\
\text { Strain } 4567 \\
\text { (Ascomycota) }\end{array}$ & $\begin{array}{l}\text { Cirsium arvense } \\
\text { (Canadian thistle) } \\
\text { (Asteraceae); ns }\end{array}$ & $\begin{array}{l}\text { Agar malt-soya dan } \\
\text { biomalt semisolid; } \\
130 \text { hari }\end{array}$ & $\begin{array}{l}\text { 3-asetil-6-hidroksi-4- } \\
\text { metil-2,3- } \\
\text { dihidrobenzofuran } \\
\text { 3-(3',5'-dihidroksi-2'- } \\
\text { metilfenil)-2-butanon } \\
\text { 4-asetil-3,4-dihidro-6,8- } \\
\text { dihidroksi-5- } \\
\text { metilisokumarin } \\
\text { 4-asetil-3,4-dihidro-6,8- } \\
\text { dihidroksi-3-metoksi- } \\
\text { 5-metilisokumarin } \\
\text { 3,4-dihidro-3,6,8- } \\
\text { trihidroksi-3,5- } \\
\text { dimetil-isokumarin } \\
\text { 6,8-diasetoksi-3,5- } \\
\text { dimetilisokumarin }\end{array}$ & \\
\hline $\begin{array}{l}\text { Microsphaeropsis } \mathrm{sp} . \\
\text { Strain NRRL } 15684 \\
\text { (mitosporic } \\
\text { Ascomycota) }\end{array}$ & $\begin{array}{l}\text { Buxus semperivens L. } \\
\text { (Buxaceae); daun }\end{array}$ & $\begin{array}{l}\text { Medium SL; } 24^{\circ} \mathrm{C} ; \\
13 \text { hari }\end{array}$ & lakton S 39163/F-I & antimikrobial;antiviral \\
\hline $\begin{array}{l}\text { Mycelia sterila } \\
\text { (Ascomycota) }\end{array}$ & $\begin{array}{l}\text { Atropa belladionna L. } \\
\text { (Solanaceae); akar }\end{array}$ & $\begin{array}{l}\text { Agar malt-soya dan } \\
\text { biomalt semisolid; } \\
\text { RT; } 70 \text { hari }\end{array}$ & $\begin{array}{l}\text { preussomerin } \mathrm{G} \\
\text { preussomerin } \mathrm{H} \\
\text { preussomerin } \mathrm{I} \\
\text { preussomerin } \mathrm{J} \\
\text { preussomerin } \mathrm{K} \\
\text { preussomerin } \mathrm{L} \\
\end{array}$ & $\begin{array}{l}\text { antibakteri;antijamur; } \\
\text { FPTase inhibitor } \\
\text { antibakteri;antijamur } \\
\text { antibakteri;antijamur } \\
\text { antibakteri;antijamur } \\
\text { antibakteri;antijamur } \\
\text { antibakteri;antijamur }\end{array}$ \\
\hline $\begin{array}{l}\text { Nectria galligena } \\
\text { (Nectriaceae) }\end{array}$ & $\begin{array}{l}\text { Malus X domestica } \\
\text { Borkch (apel) } \\
\text { (Rosaceae); xylem }\end{array}$ & $\begin{array}{l}\text { Medium MGP; } \\
24^{\circ} \mathrm{C} \text {; hingga semua } \\
\text { glukosa dikonsumsi }\end{array}$ & $\begin{array}{l}\text { kolletorin B } \\
\text { kolletoklorin B } \\
\text { ilisikolin C } \\
\text { ilisikolin E } \\
\text { ilisikolin F } \\
\alpha, \beta \text {-dehidrocurvularin }\end{array}$ & $\begin{array}{l}\text { AChE inhibitor; B- } \\
\text { glukoronidase inhibitor } \\
\text { antibakteri ; AChE } \\
\text { inhibitor; } \beta \text {-glukoronidase } \\
\text { inhibitor } \\
\text { antibakteri ; AChE } \\
\text { inhibitor; } \beta \text {-glukoronidase } \\
\text { inhibitor } \\
\text { sitotoksik; seed germination } \\
\text { radical dan penghambat } \\
\text { pertumbuhan epikotil }\end{array}$ \\
\hline $\begin{array}{l}\text { Nodulisporium } \text { sp. } \\
\text { MF 5954, ATCC } 74254 \\
\text { (microsporic } \\
\text { Xylariales) }\end{array}$ & $\begin{array}{l}\text { Bontia daphnoides L. } \\
\text { (Scrophulariaceae); } \\
\text { Kayu }\end{array}$ & $\begin{array}{l}\text { Medium nutrient; } \\
25^{\circ} \mathrm{C} ; 21-28 \text { hari }\end{array}$ & $\begin{array}{l}\text { Nodulisporic acid } \mathrm{A} \\
\text { Nodulisporic acid } \mathrm{A}_{1} \\
\text { Nodulisporic acid } \mathrm{A}_{2}\end{array}$ & $\begin{array}{l}\text { insektisida } \\
\text { insektisida }\end{array}$ \\
\hline
\end{tabular}

J. Trop. Pharm. Chem. 2011. Vol 1. No. 3. 
Jamur Endofit, Biodiversitas, Potensi Dan Prospek Penggunaannya Sebagai Sumber Bahan Obat Baru

Tabel I. Produk alami dari mikroba endofit (lanjutan)

\begin{tabular}{|c|c|c|c|c|}
\hline Jenis mikroba & $\begin{array}{c}\text { Tanaman inang } \\
\text { (family)bagian tanaman } \\
\text { atau jaringan }\end{array}$ & Kondisi kultur & Produk alami & Aktifitas biologi \\
\hline $\begin{array}{l}\text { Paecilomyces sp. H-036 } \\
\text { dan } \\
\text { W-001 } \\
\text { (Trichocomaceae) }\end{array}$ & $\begin{array}{l}\text { Taxus mairei (Lemee dan } \\
\text { Lev)dan Torreya grandis } \\
\text { Arn. (Taxaceae); kulit } \\
\text { batang }\end{array}$ & PDA ; $24^{\circ} \mathrm{C} ; 7$ hari & brefeldin A & $\begin{array}{l}\text { antijamur; antivirus } \\
\text {;antikanker; weed } \\
\text { management }\end{array}$ \\
\hline $\begin{array}{l}\text { Penicilium implicatum } \\
\text { (isolate } \mathrm{SJ} 21 \text { ) } \\
\text { (Trichocomaceae) }\end{array}$ & $\begin{array}{l}\text { Diphylleia sinensis } \mathrm{H} \text {. } \\
\text { L.Li (Berberidaceae); }\end{array}$ & $\begin{array}{l}\text { Medium MM; } 28^{\circ} \mathrm{C} \text {; } \\
6 \text { hari }\end{array}$ & $\begin{array}{l}\text { substansi analog mirip } \\
\text { podofilotoksin }\end{array}$ & antikanker \\
\hline $\begin{array}{l}\text { Penicillium janczewskii } \\
\text { (Trichocomaceae) }\end{array}$ & $\begin{array}{l}\text { Akar; rimpang; petiole } \\
\text { Prumnopitys andina } \\
\text { (Endl.)Launbenf. } \\
\text { (Podocarpaceae); phloem }\end{array}$ & PDB; $25^{\circ} \mathrm{C} ; 23$ hari & $\begin{array}{l}\text { peniprekuinolon } \\
\text { glioviktin } \\
\text { mellein }\end{array}$ & $\begin{array}{l}\text { nematisidal; pemacu } \\
\text { pertumbuhan akar; } \\
\text { sitotoksik lemah } \\
\text { antibakteri;antivirus; } \\
\text { fitotoksik }\end{array}$ \\
\hline $\begin{array}{l}\text { Periconia sp. } \\
\text { OBW-15 } \\
\text { (Halosphaeriaceae) }\end{array}$ & $\begin{array}{l}\text { Taxus cuspidate Siebold } \\
\text { Dan Zucc (Taxaceae) } \\
\text { Kulit batang bagian dalam }\end{array}$ & $\begin{array}{l}\text { Media S-7 } \\
\text { (cair)( still culture); } \\
25^{\circ} \mathrm{C} ; 21 \text { hari }\end{array}$ & $\begin{array}{r}\text { periconicin A } \\
\text { periconicin B }\end{array}$ & $\begin{array}{l}\text { antimikotik; elongasi } \\
\text { hipokotil dan inhibitor } \\
\text { pertumbuhan akar; pemacu } \\
\text { pertumbuhan akar (pada } \\
\text { low cone) } \\
\text { elongasi hipokotil dan } \\
\text { inhibitor pertumbuhan akar; } \\
\text { pemacu pertumbuhan akar } \\
\text { (pada low cone) }\end{array}$ \\
\hline Periconia spp. & Torreya grandifolia & & Taxol® & antikanker \\
\hline $\begin{array}{l}\text { Pestalotiopsis jesteri } \\
\text { (Amphisphaeriaceae) }\end{array}$ & $\begin{array}{l}\text { Fragrea bodenii Thunb. } \\
\text { (Gentianaceae)kulit batang } \\
\text { bagian dalam }\end{array}$ & $\begin{array}{l}\text { Medium agar MID ; } \\
23^{\circ} \mathrm{C} ; 21 \text { hari }\end{array}$ & $\begin{array}{l}\text { jesteron } \\
\text { hidroksijesteron }\end{array}$ & antijamur; anti mikotik \\
\hline $\begin{array}{l}\text { Pestalotiopsis } \\
\text { Microspora } \\
\text { (Amphisphaeriaceae) }\end{array}$ & $\begin{array}{l}\text { Terminalia morobensis } \\
\text { L. (Combretaceae); batang }\end{array}$ & $\begin{array}{l}\text { Medium MID (still } \\
\text { culture); } 23^{\circ} \mathrm{C} ; 21 \\
\text { hari } \\
\text { Medium MID (still } \\
\text { culture); } 23^{\circ} \mathrm{C} ; 35 \\
\text { hari }\end{array}$ & $\begin{array}{l}\text { pestacin } \\
\text { isopestacin }\end{array}$ & $\begin{array}{l}\text { antimikosis; antioksidan } \\
\text { antifungi; antioksidan }\end{array}$ \\
\hline Pestalotiopsis guepinii & $\begin{array}{l}\text { Wollemia nobilis } \\
\text { (Wollemi pine) }\end{array}$ & & Taxol® & \\
\hline $\begin{array}{l}\text { Pestalotiopsis } \\
\text { microspora }\end{array}$ & $\begin{array}{l}\text { Taxus brevifolia Nutt. } \\
\text { (Pacific Yew) }\end{array}$ & & $\begin{array}{l}\text { pestalotiopsins A } \\
\text { pestalotiopsins B }\end{array}$ & seskuiterpens \\
\hline $\begin{array}{l}\text { Pestalotiopsis } \\
\text { microspora }\end{array}$ & $\begin{array}{l}\text { Taxus wallachiana } \\
\text { (Nepalese Yew) }\end{array}$ & & Taxol® & antikarsinogenik \\
\hline $\begin{array}{l}\text { Pestalotiopsis } \\
\text { microspora }\end{array}$ & Torreya taxifolia Arn & & torreyanic acid & antikanker dan antibiotik \\
\hline $\begin{array}{l}\text { Pestalotiopsis } \\
\text { microspora }\end{array}$ & Taxodium distichum Rich & & Taxol® & antikanker \\
\hline $\begin{array}{l}\text { Pestalotiopsis spp. } \\
\text { (Amphisphaeriaceae) }\end{array}$ & $\begin{array}{l}\text { Beberapa tanaman hutan } \\
\text { hujan; daun; batang, } \\
\text { petiole }\end{array}$ & $\begin{array}{l}\text { Medium MID; } \\
\text { ditambah dengan } \\
\text { soytone }) ; 23^{\circ}- \\
24^{\circ} \mathrm{C} ; 21 \text { hari }\end{array}$ & amubuic acid & antimikosis \\
\hline Phoma spp. & $\begin{array}{l}\text { Taxus wallachiana } \\
\text { (Himalayan Yew) }\end{array}$ & & $\begin{array}{l}\text { altersolanol A } \\
\text { 2- hidroksi- 6- } \\
\text { metil asam benzoat }\end{array}$ & antibakteri(Bacillus subtilis) \\
\hline $\begin{array}{l}\text { Phomopsis phaseoli } \\
\text { (Valsaceae) }\end{array}$ & $\begin{array}{l}\text { Pohon dari daerah } \\
\text { tropis;daun }\end{array}$ & $\begin{array}{l}\text { Medium YMG; } \\
22^{\circ} \mathrm{C} ; \text { hingga } \\
\text { sumber karbon } \\
\text { diserap sempurna }\end{array}$ & 3-hidroksipropionat & nematisidal \\
\hline $\begin{array}{l}\text { Phomopsis sp. } \\
\text { (valsaceae) }\end{array}$ & $\begin{array}{l}\text { Erythrina crista-galli L. } \\
\text { (Fabaceae); twig (mati) }\end{array}$ & $\begin{array}{l}\text { Medium KGA; RT; } \\
39 \text { hari }\end{array}$ & phomol & $\begin{array}{l}\text { antibakteri; antijamur; anti- } \\
\text { inflamasi (uji edema pada } \\
\text { telinga tikus); sitotoksik } \\
\text { lemah }\end{array}$ \\
\hline $\begin{array}{l}\text { Phyllosticta capitalensis } \\
\text { (telemorf Guignardia } \\
\text { mangiferae) } \\
\text { (Botryospaeriaceae) }\end{array}$ & $\begin{array}{l}\text { Pohon kayu daerah tropis } \\
\text { dan daerah non tropis; } \\
\text { daun }\end{array}$ & $\begin{array}{l}\text { PDA }(2 \% \\
\text { Bactoagar }) ; 26^{\circ} \mathrm{C} ; \\
10 \text { hari }\end{array}$ & melanin & \\
\hline
\end{tabular}

J. Trop. Pharm. Chem. 2011. Vol 1. No. 3. 
Jamur Endofit, Biodiversitas, Potensi Dan Prospek Penggunaannya Sebagai Sumber Bahan Obat Baru

Tabel I. Produk alami dari mikroba endofit (lanjutan)

\begin{tabular}{|c|c|c|c|c|}
\hline Jenis mikroba & $\begin{array}{c}\text { Tanaman inang } \\
\text { (family)bagian tanaman } \\
\text { atau jaringan }\end{array}$ & Kondisi kultur & Produk alami & Aktifitas biologi \\
\hline $\begin{array}{l}\text { Pseudomassaria sp. } \\
\text { ATCC } 74411 \\
\text { (Hyponectriaceae) }\end{array}$ & $\begin{array}{l}\text { Tanaman belum } \\
\text { teridentifikasi (diperoleh } \\
\text { disekitar Kinshasa,Kongo); } \\
\text { daun }\end{array}$ & $\begin{array}{l}\text { WBE broth; } 25^{\circ} \mathrm{C} ; \\
21 \text { hari }\end{array}$ & $\begin{array}{l}\text { demetilsterrikuinon B1 } \\
\text { (DMAQ-B1) } \\
\text { asterikuinon } \\
\text { asterikuinon } \\
\text { produk oksidasi } 1 \\
\text { produk oksidasi } 2 \\
\text { produk dekomposisi }\end{array}$ & aktifator reseptor insulin \\
\hline Rhinocladiella spp. & $\begin{array}{l}\text { Tripterygium wilfordii } \\
\text { Hook.f. }\end{array}$ & & $\begin{array}{l}\text { 22-oxa-[12]- } \\
\text { Cytochalasin }\end{array}$ & antitumor \\
\hline $\begin{array}{l}\text { Rhizhoctonia } \mathrm{sp} . \\
\text { Cy064 } \\
\text { (mytosporic } \\
\text { Hymemomycetes) }\end{array}$ & $\begin{array}{l}\text { Cynodon dactylon (L.) } \\
\text { Pers.. (Poaceae); daun }\end{array}$ & $\begin{array}{l}\text { Medium grain-bran- } \\
\text { yeast } ; 28^{\circ} \mathrm{C} ; 40 \text { hari }\end{array}$ & $\begin{array}{l}\text { rhizoctonis acid } \\
\text { monometilsulokrin } \\
\text { ergosterol } \\
3 \beta, 5 \alpha, 6 \beta \text { - } \\
\quad \text { trihidroksiergosta- } \\
\quad \text { 7,22-diene }\end{array}$ & $\begin{array}{l}\text { antibakteri lemah } \\
\text { antibakteri lemah } \\
\text { antibakteri lemah } \\
\text { antibakteri lemah }\end{array}$ \\
\hline $\begin{array}{l}\text { Seytalidium } \mathrm{sp} . \\
\text { (mitosporic } \\
\text { Ascomycota) }\end{array}$ & Salix sp.(Saliciaceae) & $\begin{array}{l}\text { Agar malt-soya dan } \\
\text { biomalt semisolid; } \\
\text { RT; } 111 \text { hari }\end{array}$ & $\begin{array}{l}\text { 6-dihidroksi-3-metil-2-(2- } \\
\text { oksopropionil)-asam } \\
\text { benzoate } \\
\text { (1-asetil-2-hidroksivinil)- } \\
\text { 4,4-dihidroksi-3- asam } \\
\text { metil benzoate } \\
\text { asetil-3,4-dihidro-6,8- } \\
\text { dihidroksi-5- } \\
\text { metilisokumarin } \\
\text { asetil-3,4-dihidro-6,8- } \\
\text { dihidroksi-3-metoksi-5- } \\
\text { metilisokumarin } \\
\text { dekarboksisitrinon } \\
\text { 8-dihidroksi-4- } \\
\text { hidroksimetil-3,5- } \\
\text { dimetilisokromen-1-one } \\
\text { asetoksimetil-6,8- } \\
\text { dihidroksi-5-metil-2- } \\
\text { benzopiran-1-one } \\
\text { asetil-6,8-dihidroksi-5- } \\
\text { metil-2-benzopiran-1- } \\
\text { one } \\
\text {-didihidronaftol(1,2-b)- } \\
\text { furan-5,6 dikarboksilat } \\
\text { anhidrat } \\
\text { ceton adduct of } \\
\text { atronenetinone }\end{array}$ & \\
\hline $\begin{array}{l}\text { Seimatoantlerium } \\
\text { tepuiense }\end{array}$ & $\begin{array}{l}\text { Maguireothamnus } \\
\text { speciosus (N. F. Brown) } \\
\text { Steyern }\end{array}$ & & Taxol® & \\
\hline $\begin{array}{l}\text { Sporormia minima, } \\
\text { Trichothecium spp. dan } \\
\text { Jamur dimorphic } \\
\text { (belum teridentifikasi) }\end{array}$ & $\begin{array}{l}\text { Taxus wallachiana } \\
\text { (Himalayan Yew) }\end{array}$ & & paclitaxel & \\
\hline $\begin{array}{l}\text { Serratia marcescens } \\
\text { MSU-97 } \\
\text { (Enterobacteriaceae) }\end{array}$ & $\begin{array}{l}\text { Rhnycholacis penicillata } \\
\text { Tul. (Podostemaceae) }\end{array}$ & $\begin{array}{l}\text { Medium PD- } \\
\text { soytone-yeast } \\
\text { ekstrak; } 23^{\circ} \mathrm{C} ; 15 \\
\text { hari }\end{array}$ & (-)-oocydin A & anti jamur \\
\hline $\begin{array}{l}\text { Streptomyces } \\
\text { aureofaciens } \\
\text { CMUAc } 130 \\
\text { (Streptomycetaceae) }\end{array}$ & $\begin{array}{l}\text { Zingiber officinale Roscoe } \\
\text { (Zingiberacea); akar }\end{array}$ & $\begin{array}{l}\text { ISP-2 broth; } 30^{\circ} \mathrm{C} ; 5 \\
\text { hari }\end{array}$ & $\begin{array}{l}\text { 5,7-dimetoksi-4- } \\
\text { fenilkumarin } \\
\text { 5,6-dimetoksi-4-(p- } \\
\text { metoksi- } \\
\text { fenil)kumarin } \\
\text { vanillin } \\
\text { 3-metoksi- } \\
\text { 4hidroksitoluen }\end{array}$ & $\begin{array}{l}\text { antijamur } \\
\text { antijamur } \\
\text { antijamur lemah } \\
\text { antijamur lemah }\end{array}$ \\
\hline
\end{tabular}


Jamur Endofit, Biodiversitas, Potensi Dan Prospek Penggunaannya Sebagai Sumber Bahan Obat Baru

Tabel I. Produk alami dari mikroba endofit (lanjutan)

\begin{tabular}{|c|c|c|c|c|}
\hline Jenis mikroba & $\begin{array}{c}\text { Tanaman inang } \\
\text { (family)bagian tanaman } \\
\text { atau jaringan }\end{array}$ & Kondisi kultur & Produk alami & Aktifitas biologi \\
\hline $\begin{array}{l}\text { Streptomyces griceus } \\
\text { subsp. } \\
\text { Strain HKI0 } 412 \\
\text { (Streptomycetaceae) }\end{array}$ & $\begin{array}{l}\text { Kandelia candel }(\mathrm{L}) . \\
\text { Druce (Rhizhosporaceae) } \\
\text { [mangrove]; batang }\end{array}$ & $\begin{array}{l}\text { Medium I ; } 28^{\circ} \mathrm{C} ; 5 \\
\text { hari }\end{array}$ & $\begin{array}{l}\text { 7-(4-aminofenil)-2,4- } \\
\text { dimetil-7-okso-hept- } \\
\text { 5-asam enoat } \\
\text { 9-(4-aminofenil)-7- } \\
\text { hidroksi-2,4,6- } \\
\text { trimetil-9-okso-non- } \\
\text { 2-asam enoat } \\
\text { 12-(4-aminofenil)-10- } \\
\text { hidroksi-6-(1- } \\
\text { hidroksietil)-7,9- } \\
\text { dimetil-12-okso- } \\
\text { dodeca-2,4-asam } \\
\text { dienoat. }\end{array}$ & \\
\hline $\begin{array}{l}\text { Streptomyces sp. } \\
\text { NRRL } 30562 \\
\text { (Streptomycetaceae) }\end{array}$ & $\begin{array}{l}\text { Kennedia nigricans } \\
\text { Lindley (Fabaceae); batang }\end{array}$ & $\begin{array}{l}\text { PDB still culture; } \\
23^{\circ} \mathrm{C} ; 5 \text { hari }\end{array}$ & munumbacins A-D & antibiotik \\
\hline $\begin{array}{l}\text { Streptomyces sp. } \\
\text { NRRL } 30566 \\
\text { (Streptomycetaceae) }\end{array}$ & $\begin{array}{l}\text { Grevillia pteridifolia J. } \\
\text { Knight (Proteaceae); } \\
\text { batang }\end{array}$ & $\begin{array}{l}\text { DIFCO nutrient } \\
\text { broth; } 25^{\circ} \mathrm{C} ; 21-28 \\
\text { hari }\end{array}$ & kakadumisin $\mathrm{A}$ & antibiotik \\
\hline $\begin{array}{l}\text { Streptomyces sp. } \\
\text { MSU-2110 } \\
\text { (Streptomycetaceae) }\end{array}$ & $\begin{array}{l}\text { Monstera } \mathrm{sp} \\
\text { (Aracaceae); batang }\end{array}$ & $\begin{array}{l}\text { Medium PSNB, still } \\
\text { culture } ; 25^{\circ} \mathrm{C} ; 21-28 \\
\text { Hari }\end{array}$ & coronamysin & antibiotik \\
\hline Taxomyces andreanae & $\begin{array}{l}\text { Taxus brevifolia Nutt. } \\
\text { (Pacific Yew) }\end{array}$ & & Taxol® & $\begin{array}{l}\text { antikarsinogenik }(\mathrm{P}-388, \mathrm{P}- \\
1534, \alpha-1210 \text { murine } \\
\text { leukaemia, Walker } 256 \\
\text { carcinoma, sarcoma } 180)\end{array}$ \\
\hline Tubercularia spp. & $\begin{array}{l}\text { Taxus mairie (Chinese } \\
\text { southern Yew) }\end{array}$ & & Taxol® & $\begin{array}{l}\text { antikanker (sel P388, } \\
\text { Sel KB) }\end{array}$ \\
\hline $\begin{array}{l}\text { Xylaria sp. No. } 2508 \\
\text { (Xylariaceae) }\end{array}$ & $\begin{array}{l}\text { Pohon mangrove yang } \\
\text { belum teridentifikasi; biji }\end{array}$ & $\begin{array}{l}\text { Dekstosa }(1,2 \%) \\
\text { Ekstrak yeast }(0,1 \%) \\
\text { Peptone }(0,2 \%) \\
\mathrm{NaCl}(3,0 \%) ; \\
30^{\circ} \mathrm{C} ; 86 \text { jam }\end{array}$ & $\begin{array}{l}\text { asam piliformat } \\
\text { ergosterol } \\
3 \beta, 5 \alpha, 6 \beta \text { - } \\
\quad \text { trihidroksiergosta- } \\
\quad 7,22 \text {-diena } \\
\alpha \text {-gliserol monopalmitat } \\
\text { asam p-hidroksibenzoat }\end{array}$ & \\
\hline $\begin{array}{l}\text { Jamur yang belum } \\
\text { teridentifikasi CR115 } \\
\text { (90\% hampir mirip } \\
\text { dengan Basidiomycetes } \\
\text { yang belum } \\
\text { terkarakterisasi dari } \\
\text { akar oat) }\end{array}$ & $\begin{array}{l}\text { Daphnosis Americana } \\
\text { (Miller)J.S. Johnson } \\
\text { (Thymelaeceae); }\end{array}$ & PDB & $\begin{array}{l}\text { guanacastepen } \mathrm{A} \\
\text { guanacastepen B } \\
\text { guanacastepen } \mathrm{C} \\
\text { guanacastepen D } \\
\text { guanacastepen } \mathrm{E} \\
\text { guanacastepen } \mathrm{F} \\
\text { guanacastepen } \mathrm{G} \\
\text { guanacastepen H } \\
\text { guanacastepen I } \\
\text { guanacastepen } \mathrm{J} \\
\text { guanacastepen } \mathrm{K} \\
\text { guanacastepen } \mathrm{L} \\
\text { guanacastepen } \mathrm{M} \\
\text { guanacastepen } \mathrm{N} \\
\text { guanacastepen } \mathrm{O}\end{array}$ & $\begin{array}{l}\text { antibakteri } \\
\text { antibakteri }\end{array}$ \\
\hline $\begin{array}{l}\text { Fungi yang belum } \\
\text { terindetifikasi } \\
\text { No. } 2534\end{array}$ & $\begin{array}{l}\text { Kandelia candel (L.) } \\
\text { Druce (Rhizophoraceae); } \\
\text { dropper }\end{array}$ & & $\begin{array}{l}3 \beta, 8 \alpha, 6 \beta- \\
\text { trihidroksiergosta-7,22- } \\
\text { diena } \\
\text { cyclo-(Phe-Phe) } \\
\text { cyclo-(Leu-Tyr) } \\
\text { guanidin } \\
\text { 4-hidroksi-2- } \\
\text { metoksiasetopenon } \\
\text { asam protocatechuic } \\
\text { metil ester }\end{array}$ & \\
\hline $\begin{array}{l}\text { Fungi yang belum } \\
\text { terindetifikasi } \\
\text { E-3 }\end{array}$ & $\begin{array}{l}\text { Prumnopitys andina } \\
\text { (Endl.)Laubenf. } \\
\text { (Podocarpaceae); phloem }\end{array}$ & PDA; $25^{\circ} \mathrm{C} ; 23$ hari & $\begin{array}{l}\text { mellein } \\
p \text {-hidroksibenzaldehid } \\
\text { 4-(2-hidroksietil)fenol }\end{array}$ & $\begin{array}{l}\text { antibakteri; antivirus; } \\
\text { fitotoksik }\end{array}$ \\
\hline
\end{tabular}

J. Trop. Pharm. Chem. 2011. Vol 1. No. 3. 
Jamur Endofit, Biodiversitas, Potensi Dan Prospek Penggunaannya Sebagai Sumber Bahan Obat Baru

Tabel I. Produk alami dari mikroba endofit (lanjutan)

\begin{tabular}{|c|c|c|c|c|}
\hline Jenis mikroba & $\begin{array}{c}\text { Tanaman inang } \\
\text { (family)bagian tanaman } \\
\text { atau jaringan }\end{array}$ & Kondisi kultur & Produk alami & Aktifitas biologi \\
\hline $\begin{array}{l}\text { Fungi yang belum } \\
\text { teridentifikasi No.1893 }\end{array}$ & $\begin{array}{l}\text { Kandelia candel (DC). } \\
\text { Weight \& Arn } \\
\text { (Rhizhosporaceae) } \\
\text {; dropper }\end{array}$ & $\begin{array}{l}\text { GYT broth; } 30^{\circ} \mathrm{C} ; 5- \\
7 \text { hari }\end{array}$ & $\begin{array}{l}\text { lakton } 1893 \mathrm{~A} \\
\text { lakton } 1893 \mathrm{~B} \\
\text { cyclo (Phe-Gly) } \\
\text { cyclo }(\text { Ser-Leu) } \\
\text { 5-(p-hidroksilbenzil)- } \\
\quad \text { hidantoin }\end{array}$ & \\
\hline $\begin{array}{l}\text { Fungi yang belum } \\
\text { terindetifikasi } \\
\text { Strain SWS } 1111 \\
\text { (DAOM 221611) }\end{array}$ & $\begin{array}{l}\text { Picea glauca (Moench) } \\
\text { Voss. (Pinaceae); needles }\end{array}$ & $\begin{array}{l}\text { Medium MEA; } \\
20^{\circ} \mathrm{C} ; 12 \text { hari }\end{array}$ & $\begin{array}{l}\text { vermiculin } \\
\text { trans-3-metildodek-cis- } \\
\text { 6-en-4-olida } \\
\text { trans-8-hidroksi-3- } \\
\text { metildodek-cis-6-en- } \\
\text { 4-olida } \\
\text { trans-8-asetoksi-3- } \\
\text { metildodek-cis-6-en- } \\
\text { 4-olida } \\
\text { trans-9-hidroksi-3-metil- } \\
\text { 8-okso-dodec-trans- } \\
\text { 6-en-4-olida } \\
\text { trans-8,9-dihidroksi-3- } \\
\text { metil-dodek-cis-6- } \\
\text { en-4-olida } \\
\text { trans-9-hidroksi-8-okso- } \\
\text { 3-metil-dodecan-4- } \\
\text { olida } \\
\text { trans-7,9-dihidroksi-3- } \\
\text { metil-8-okso- } \\
\text { dodecan-4-olida } \\
\text { trans-6-hidroksimetil-3- } \\
\text { metil-7-okso- } \\
\text { dodecan-4-olida } \\
\text { 7a,8 } 8 \text {-11- } \\
\text { trihidroksidriman } \\
\text { Asam10,11- } \\
\text { dihidroksifarnesic }\end{array}$ & \\
\hline $\begin{array}{l}\text { Fungi yang belum } \\
\text { terindetifikasi } \\
\text { Strain SWS 2611L } \\
\text { (DAOM 229644) }\end{array}$ & $\begin{array}{l}\text { Picea glauca }(\text { Moench) } \\
\text { Voss. (Pinaceae); needles }\end{array}$ & $\begin{array}{l}\text { Medium CZ Met } \\
\text { dan } 2 \% \text { Medium } \\
\text { ekstrak malt; } \\
20^{\circ} \mathrm{C} ; 42 \text { hari }\end{array}$ & $\begin{array}{l}\text { 6,7-dihidroksi-2-propil- } \\
\text { 2,4-oktadien-4-olida } \\
\text { 5,6,8-trihidroksi-4-(1'- } \\
\quad \text { hidroksietil) } \\
\quad \text { isokumarin } \\
\text { sescandelin } \\
\text { sescandelin B } \\
\text { 4-hidroksi-2- } \\
\text { metoksiasetanilida }\end{array}$ & $\begin{array}{l}\text { toksik terhadap spruce } \\
\text { budworm cell line CF-1 } \\
\text { kurang toksik terhadap } \\
\text { spruce budworm cell line } \\
\text { CF-1 } \\
\text { kurang toksik terhadap } \\
\text { spruce budworm cell line } \\
\text { CF-1 } \\
\text { kurang toksik terhadap } \\
\text { spruce budworm cell line } \\
\text { CF-1 }\end{array}$ \\
\hline $\begin{array}{l}\text { Fungi yang belum } \\
\text { terindetifikasi } \\
\text { No.2524 }\end{array}$ & $\begin{array}{l}\text { Avicenna marinna } \\
\text { Forssk.(Acanthaceae); } \\
\text { biji[mangrove] }\end{array}$ & $\begin{array}{l}\text { GPY } \\
\text { broth(mengandung } \\
20 \% \text { airlaut); } 28^{\circ} \mathrm{C} ; \\
5-7 \text { hari }\end{array}$ & $\begin{array}{l}\text { (3SAR)-dihidroksi-(6S)- } \\
\text { undesil- } \alpha \text {-piranon } \\
\text { cyclo-(L-Phe-L-Leu'-L- } \\
\left.\text { Leu }^{2}-\mathrm{L}-\mathrm{Leu}^{3}-\mathrm{L}-\mathrm{Ile}\right)\end{array}$ & $\begin{array}{l}\text { nonsitotoksik } \\
\text { nonsitotoksik } \\
\end{array}$ \\
\hline $\begin{array}{l}\text { Fungi yang belum } \\
\text { terindetifikasi } \\
\text { No. } 2533\end{array}$ & $\begin{array}{l}\text { Avicenna marinna } \\
\text { Forssk.(Acanthaceae); } \\
\text { daun muda }\end{array}$ & $\begin{array}{l}\text { Medium glukosa- } \\
\text { daging sapi-ekstrak } \\
\text { yeast (mengandung } \\
5 \% \text { airlaut);30 }{ }^{\circ} \mathrm{C} ; 5- \\
7 \text { hari }\end{array}$ & $\begin{array}{l}\text { vermopiron } \\
\text { avicennin A } \\
\text { avicennin B } \\
\text { 5-dikloroavicennin A } \\
\text { 6,7-dimetil-8-hidroksi-3- } \\
\quad \text { metilisokumarin } \\
\text { ergosterol } \\
\text { 5 } \alpha, 8 \alpha \text { - } \\
\text { epidioksiergosterol }\end{array}$ & \\
\hline
\end{tabular}


Berdasarkan bioaktifitasnya, dikenal beberapa metabolit endofit yang berkhasiat sebagai:

\section{Antibiotik yang dihasilkan oleh mikroba endofit berupa jamur, bakteri, dan Streptomycetes.}

Cryptocandin adalah antifungi yang dihasilkan oleh mikroba endofit Cryptosporiopsis quercina yang berhasil diisolasi dari tanaman obat Tripterigeum wilfordii, dan memiliki aktivitas sebagai antijamur yang patogen terhadap manusia yaitu Candida albicans dan Trichopyton spp. Beberapa zat aktif lain yang diisolasi dari mikroba endofit misalnya ecomycin diproduksi oleh Pseudomonas viridiflava juga aktif terhadap Cryptococcus neoformans dan Candida albicans yaitu jamur penyebab penyakit kuku dan kulit. Cryptocin, sebuah asam tetramat unik, yang juga dihasilkan oleh mikroba endofit Cryptosporiopsis quercina memiliki aktifitas poten melawan Pyricularia oryzae, organisme penyebab penyakit pada tanaman.

Pestalotiopsis microspora, merupakan mikroba endofit yang paling sering ditemukan di tanaman hutan lindung di seluruh dunia. Endofit ini menghasilkan metabolit sekunder ambuic acid yang berkhasiat sebagai antifungi.

Phomopsichalasin, merupakan metabolit sekunder yang diisolasi dari mikroba endofit Phomopsis sp., berkhasiat sebagai anti bakteri terhadap Bacillus subtilis, Salmonella enterica, Staphylococcos aureus, dan juga dapat menghambat pertumbuhan jamur Candida tropicalis.

Ecomycin merupakan lipopeptida yang disamping terdiri dari molekul asam amino yang umum juga mengandung homoserin dan beta-hidroksi asam aspartat, dihasilkan dari Pseudomonas viridiflava, dapat menghambat pertumbuhan Candida albicans dan

Cryptococcus neoformans. Antibiotika berspektrum luas yang disebut munumbicin, dihasilkan oleh endofit Streptomyces spp. strain NRRL 30562 yang merupakan endofit yang diisolasi dari tanaman Kennedia nigriscans, dapat menghambat pertumbuhan bakteri Bacillus anthracis, dan Mycobacterium tuberculosis yang multiresisten terhadap berbagai obat anti TBC. Jenis endofit lainnya yang juga menghasilkan antibiotika berspektrum luas adalah mikroba endofit yang diisolasi dari tanaman Grevillea pteridifolia. Endofit ini menghasilkan metabolit kakadumycin yang berasal dari endofit Streptomyces $s p$. (NRRL 30566), Aktifitas antibakterinya sama seperti munumbicin D, dan kakadumycin ini juga berkhasiat sebagai anti malaria [10]. Jamur endofit Muscodor albus yang berasal dari dahan tanaman Cinnamomum zelyanicum, menghasilkan komponen mudah menguap (antibiotic volatile) yang secara efektif menghambat dan membunuh jenis bakteri dan jamur lainnya [10].

\section{Antivirus yang dihasilkan oleh mikroba endofit.}

Aktifitas menghambat pertumbuhan virus, merupakan manfaat lain yang lebih menarik dari metabolit jamur endofit. Beberapa contoh diantaranya Cytonic acid A dan B, merupakan hCMV (human cytomegalovirus) protease inhibitors yang diisiolasi dari solid-state fermentation (SSF) jamur endofit Cytonema sp. Metabolit ini memiliki struktur molekul yang merupakan isomer p-tridepside, berhasiat sebagai anti [10]. 


\section{Antikanker yang dihasilkan oleh mikroba endofit.}

Paclitaxel dan derivatnya merupakan zat yang berkhasiat sebagai antikanker yang pertama kali ditemukan yang diproduksi oleh mikroba endofit. Paclitaxel merupakan senyawa diterpenoid yang didapatkan dalam tanaman Taxus spp. Senyawa yang dapat mempengaruhi pembentukan tubulin dalam proses pembelahan sel-sel kanker ini, juga diproduksi oleh endofit Pestalotiopsis microspora, yang diisolasi dari jamur Taxomyces andreanae, $T$. brevifolia, dan $T$. wallichiana. Saat ini beberapa jenis endofit lainnya telah dapat diisolasi dari berbagai jenis Taxus dan didapatkan berbagai senyawa yang berhasiat sebagai anti tumor. [10].

\section{Antimalaria yang dihasilkan oleh mikroba endofit.}

Colletotrichum sp. merupakan endofit yang diisolasi dari tanaman Artemisia annua, menghasilkan metabolit artemisinin yang sangat potensial sebagai antimalaria. Disamping itu beberapa mikroba endofit yang diisolasi dari tanaman Cinchona spp, juga mampu menghasilkan alkaloid cinchona yang dapat dikembangkan sebagai sumber bahan baku obat anti malaria [10].

\section{Antioksidan yang dihasilkan oleh mikroba endofit.}

Pestacin dan isopestacin merupakan metabolit sekunder yang dihasilkan oleh endofit $P$. microspora. Endofit ini berhasil diisolasi dari tanaman Terminalia morobensis, yang tumbuh di Papua New Guinea. Pestacin ataupun isopestacin berhasiat sebagai antioksidan, aktivitas ini dimiliki diduga karena struktur molekulnya yang mirip dengan [10].

\section{Insektisida yang dihasilkan oleh mikroba endofit.}

Beberapa endofit ternyata memiliki aktifitas anti serangga, nodulisporic acids dihasilkan oleh endofit Nodulisporium sp. dari tanaman Bontia daphnoides, merupakan insektisida yang poten terhadap larva serangga. Penemuan senyawa baru ini menuntun ke penemuan senyawa lain yang lebih poten. [10]

\section{Antidiabetes (aktifator reseptor insulin) yang dihasilkan oleh mikroba endofit.}

Endofit Pseudomassaria sp yang diisolasi dari tanaman yang ada dihutan lindung dekat Kinshasa, Kongo, menghasilkan metabolit sekunder yang bekerja seperti insulin. Senyawa ini sangat menjanjikan karena tidak sebagaimana insulin, senyawa ini tidak rusak jika diberikan peroral. Dalam uji praklinik terhadap binatang coba membuktikan bahwa aktivitasnya sangat baik dalam menurunkan glukosa darah tikus yang diabetes. Hasil tersebut diperkirakan dapat menjadi awal dari era baru terapi mengatasi diabetes dimasa mendatang [10].

\section{Senyawa imunosupresif yang dihasilkan oleh mikroba endofit.}

Obat-obat imunospresif merupakan obat yang digunakan untuk pasien yang akan mengalami tindakan transplantasi organ. Selain itu imunosupresif juga dapat digunakan untuk mengatasi penyakit autoimum seperti rematoid artritis dan insulin dependent diabetes. Senyawa subglutinol A dan B yang dihasilkan oleh endofit Fusarium subglutinans yang diisolasi dari tanaman T. wilfordii, diketahui merupakan senyawa imunosupresif yang sangat poten [10]. 


\section{Prospek Endofit Indonesia Sebagai Sumber Bahan Baku Obat}

Endofit yang diisolasi dari suatu tanaman obat dapat menghasilkan metabolit sekunder yang sama dengan tanaman aslinya atau berbeda namun khasiat yang dipunyai bisa sangat beragam seperti yang telah dilaporkan oleh para peneliti. Endofit sebagai sumber bahan berkhasiat dapat dikultivasi dalam waktu singkat untuk kemudian diekstraksi metabolit sekundernya, apabila hal ini diterapkan untuk tanaman kemungkinan besar memerlukan puluhan tahun untuk dapat dipanen dan kemudian baru diekstraksi. Indonesia sebagai salah satu negara dengan biodivesitas hayati yang kedua didunia setelah Brazil, memiliki prospek yang cerah sebagai sumber produk bahan alam yang berasal dari endofit. Hal ini ditunjang dengan kekayaan variasi lahan di Indonesia dari dataran rendah yang kering hingga dataran tinggi atau pegunungan yang sejuk dan lembab memberikan kekayaan jenis tumbuhan yang sangat beragam. Peran masyarakat lokal sebagai sumber informasi etnobotani untuk penemuan sumber mikroba endofit baru juga sangat diperlukan. Kekayaan budaya Nusantara didukung pengetahuan tentang tumbuhan obat berkhasiat memberi peluang pemanfaatan endofit dari hutan yang ada di Indonesia sebagai salah satu negara penghasil bahan baku obat herbal ataupun modern. Mengkaji hal-hal di atas pelestarian dan penyelamatan hutan sebagai sumber daya hayati mutlak harus dilakukan.

\section{KESIMPULAN}

Endofit merupakan bagian dari biodiversitas yang ada di bumi, mikroorganime ini ditemukan dalam jaringan hidup dari tanaman inang. Endofit berkontribusi menghasilkan metabolit sekunder yang memiliki karateristik tertentu. Metabolit sekunder yang dihasilkan oleh endofit memiliki kegunaan dalam bidang pengobatan modern seperti antibiotik, antikanker, antioksidan, antimalaria, antidiabetes dan imunosupresif disamping manfaatnya yang juga sangat besar bagi pertanian.

\section{PENUTUP}

Tumbuhan merupakan sumber bahan baku obat yang tak ternilai harganya, perlu terus menerus mendapat perhatian kita semua. Ekploitasi hutan dan tanaman obat yang berlebihan tanpa memperhatikan upaya konservasinya tentu sangat mengkhawatirkan. Peran ahli budidaya tanaman dan bioteknologi sangat penting untuk menghindari kelangkaan bahan baku obat yang beberapa diantaranya sampai saat ini masih diambil dari tanaman aslinya secara konvensional. Melalui pemanfaatan bioteknologi produksi metabolit sekunder dapat dilakukan secara in- vitro dalam skala besar secara berkesinambungan, demikian pula rekayasa genetika dan transformasi genetik dapat membantu meningkatkan produksi metabolit sekunder.

Pemanfaatan endofit dalam produksi metabolit sekunder di Indonesia seharusnya lebih ditingkatkan, mengingat potensi Indonesia sebagai negara dengan biodiversitas yang tinggi belum dimanfaatkan secara maksimal. Peran aktif dari pemerintah dan industri sebagai penyandang dana riset sangat diperlukan agar penelitian endofit ini dapat dilakukan secara berkesinambungan. Selain itu juga kerjasama riset perguruan tinggi dan industri dalam mengembangkan peran endofit sebagai sumber bahan obat dan senyawa agrokimia sangat diperlukan. 


\section{DAFTAR PUSTAKA}

1. Aminullah E., 1985. Perkembangan Penerapan Bioteknologi dan Rekayasa Genetik Dalam Kesehatan. Cermin Dunia Kedokteran No. 38: $52-55$

2. Gunatilaka A.A., 2006. Natural Products from Plant-Associated Microorganism: Distribution, Structural Diversity, Bioactivity, and Implications of Their Occurrence. J. Nat. Prod. 2006. 69: 509-526

3. Lu, H.; Zou, W.X.; Meng, J.C.; Hu, J.; \& Tan, R.X. 2000, New Bioactive Metabolites Produced by Colletotrichum sp., an Endophytic Fungus in Artemisia annua. Plant Sci. 151: 7376

4. Maksum, R. 2005, Peranan Bioteknologi dan Mikroba Endofit Dalam Perkembangan Obat Herbal. Maj. Ilmu Kefarmasian Indonesia. Vol.II, No.3. Desember 2005: 113-126

5. Prasetyoputri, A.; \& Atmosukarto, I. 2006, Mikroba Endofit: Sumber Molekul Acuan Baru yang Berpotensi. BioTrends. Vol I. No.2. 2006: 13-15

6. Proksch, P.; Edrada, R.A.; \& Ebel, R. 2003, Review: Drugs from the Sea - Opportunities and Obstacles. Mar. Drugs 1, 5-17.
7. Schulz, B.; \& Boyle, C. 2006, What Are Endophytes? dalam: Schulz, B.; Boyle, C.; \& Sieber, T.N. (Eds.). Soil Biology. Volume 9. Microbial Root Endophytes. Springer-Verlag. Berlin Heidelberg. 2006: 1-13.

8. Strobel, G.A. 2002, Microbial gifts from rain forests. Can. J. Plant Pathol. 24: 14-20.

9. Strobel, G.A.; \& Daisy, B. 2003, Bioprospecting for Microbial Endophytes and Their Natural Products. Microbiol.and Mol. Biology Rev. Dec 2003. Vol.67. No. 4: 491502.

10. Strobel, G.A.; Daisy, B.; Castillo, U.; \& Harper, J. 2004, Natural Product from Endophytic Microorganism. J. Nat. Prod. 2004. 67: 257-268

11. Strobel, G.A.; Miller, R.V.; Miller, C.; Condron, M.; Teplow, D.B.; \& Hess W.M. 2000, Cryptocandin, a potent antimycotic from endophytic fungus Cryptosporiopsis quercina. Microbiology 145: 1919-1926.

12. Tejesvi, M.V.; Nalini, M.S.; Mahesh, B.; Prakash, H.S.; Kini, K.R.; Shetty, H.S.; \& Ven, S. 2007, New Hopes From Endhopythic Fungal Secondary metabolite. Bol. Soc. Quím. Méx., 1(1): 19-26

13. Tan, R.X.; \& Zou, W.X. 2001, Endophytes: a rich source of functional metabolites. Nat. Prod. Rep. 18 : 448-459 